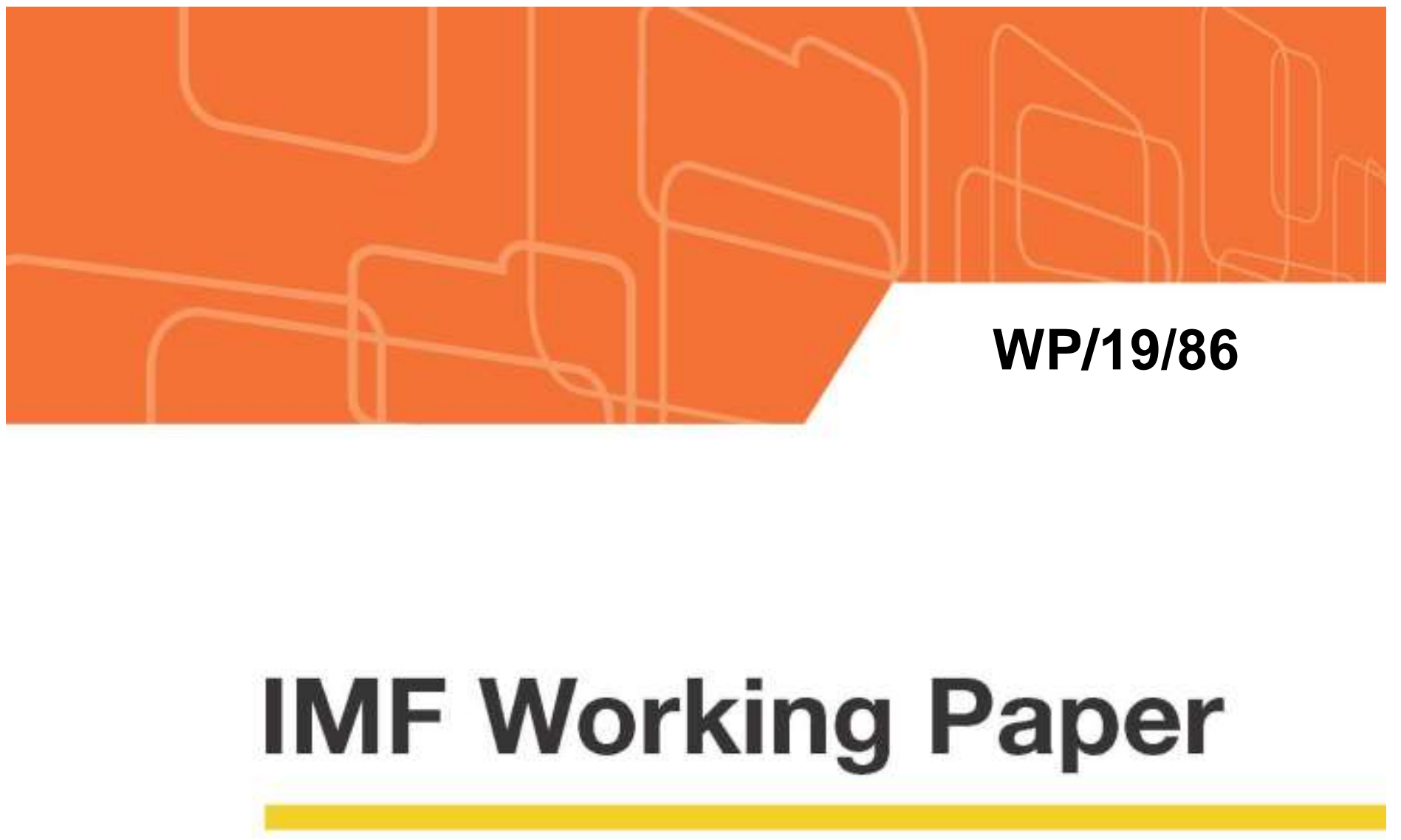

\title{
Conceptual Issues in Calibrating the Basel III Countercyclical Capital Buffer
}

\author{
by Torsten Wezel
}

IMF Working Papers describe research in progress by the author(s) and are published to elicit comments and to encourage debate. The views expressed in IMF Working Papers are those of the author(s) and do not necessarily represent the views of the IMF, its Executive Board, or IMF management. 


\title{
IMF Working Paper
}

Monetary and Capital Markets Department

\section{Conceptual Issues in Calibrating the Basel III Countercyclical Capital Buffer Prepared by Torsten Wezel}

Authorized for distribution by Martin Cihak

May 2019

\section{IMF Working Papers describe research in progress by the author(s) and are published to elicit comments and to encourage debate. The views expressed in IMF Working Papers are those of the author(s) and do not necessarily represent the views of the IMF, its Executive Board, or IMF management.}

\begin{abstract}
This paper discusses issues in calibrating the countercyclical capital buffer (CCB) based on a sample of EU countries. It argues that the main indicator for buffer decisions under the Basel III framework, the credit-to-GDP gap, does not always work best in terms of covering bank loan losses that go beyond what could be expected from economic downturns. Instead, in the case of countries with short financial cycles and/or low financial deepening such as transition and developing economies, the Basel gap is shown to work best when computed with a low, smoothing factor and adjusted for the degree of financial deepening. The paper also analyzes issues in calibrating an appropriate size of the CCB and, using a loss function approach, points to a tradeoff between stability of the buffer size and cost efficiency considerations.
\end{abstract}

JEL Classification Numbers: C2, G2

Keywords: Macroprudential Policy, Procyclicality, Basel III

Author's Email Address: twezel@imf.org 


\section{INTRODUCTION}

The countercyclical capital buffer ( $\mathrm{CCB}$, sometimes abbreviated $\mathrm{CCyB})$ is a key innovation introduced by the Basel III framework in response to the global financial crisis. The CCB represents an additional capital layer of typically up to 2.5 percent of risk-weighted assets (RWA) that can be released so that banks may absorb burgeoning losses during a prolonged downturn while maintaining the flow of credit to the economy. The hope is that the CCB moderates the flow of credit to the economy when credit and asset developments point to a rise in systemic risk and so require accumulation of the CCB. As such, the CCB has the macroprudential objective of safeguarding financial stability by shoring up bank capital ahead of times of distress, thereby enabling banks to continue lending to the real economy instead of restricting credit supply with procyclical effects, as happened in the recent crisis. On the other hand, time-varying capital requirements may as such affect the credit supply (Aiyar and others 2014a/2014b; Forbes and others 2016). Notwithstanding the overall beneficial property, some questions remain about the calibration of the appropriate size of the CCB across a spectrum of countries, particularly when they comprise cases with short financial cycles and low financial deepening.

Already in 2010, the Basel Committee for Banking Supervision (BCBS) issued detailed guidance on how to operate the CCB (BCBS 2010), including a buffer guide as input to the decision making of national authorities linking the accumulation of the CCB to a particular specification of the so-called credit-to-GDP gap (hereafter also "credit gap"). This guide is based on prior research pointing to superior performance of the gap in predicting systemic banking crises (Drehmann and others 2010). Following the BCBS recommendation, the European Union (EU; 2013) decided to prescribe that the CCB "should be built up when aggregate growth in credit and other asset classes with a significant impact on the risk profile of such credit institutions and investment firms are judged to be associated with a build-up of system-wide risk, and drawn down during stressed periods" (Capital Requirements Directive (CRD IV), preamble, recital (80)) and that the CCB buffer guide "shall be based on the deviation of the ratio of credit-to-GDP from its long-term trend" (CRD IV, Article 136(2)). While the legal text calls for taking into account "levels of credit within that jurisdiction," suggesting the use of total credit rather than merely bank credit, it does not expressly prescribe any particular method of calculating the credit gap ${ }^{1}$.

Support for the credit-to-GDP gap is not unequivocal. While several studies have confirmed the good predictive quality of the credit gap and thus its usefulness for triggering the CCB buildup $^{2}$ (see Detken and others, 2014, for an overview), it has also been met with criticism,

\footnotetext{
${ }^{1}$ Nevertheless, the EU directive refers to guidelines of the European Systemic Risk Board (ESRB) in this matter.

${ }^{2}$ By contrast, triggers for the release phase have been studied much less, although researchers coincide in that the trigger needs to be based on market data since, despite all efforts to accurately predict their coming, crises hit
}

(continued...) 
mainly based on the argument that its signaling properties may not work well at certain points of the cycle and in countries undergoing structural change. For example, Geršl and Seidler (2011) posit that the BCBS (2010) gap method incorrectly signals excessive credit growth for a number of Central and Eastern European countries - a finding echoed by Bendoratyte and Kaupelyte (2013). Repullo and Saurina (2011) find for advanced countries that the gap's correlation with GDP growth is generally negative, implying that capital requirements are reduced when GDP growth is high and vice versa, although, as Drehmann and Tsatsaronis (2014) contend, the negative correlation is less pronounced when excluding periods of buffer deactivation. Kauko (2012) proposes to smooth GDP as denominator in the credit-to-GDP ratio over a five-year period to guard against instances in which the gap keeps rising into a crisis due to a sudden drop in output (as found by Repullo and Saurina, 2011, for mature economies, and Krüger and Libertucci, 2013, for Italy). Bonfim and Monteiro (2013) posit that the gap may issue confusing signals in the presence of profound structural change when financial liberalization and privatization critically drive credit extension, as was the case in many emerging economies. This structural change does make it difficult to distinguish growing financial sector vulnerabilities from the convergence to a new steady state.

Alternative credit-based indicators have been proposed. Similar to the BCBS approach, Kelly and others (2011) suggest basing the buffer size on deviations from an estimated steady state in the credit-to-GDP ratio. Others have voiced fundamental concerns about the filtering technique underlying the gap calculation. Pointing to a statistical issue, Edge and Meisenzahl (2011) and Farrell (2014) stress the unreliability of the credit gap in real time,

notwithstanding its signaling quality. This is because ex post revisions to the gap figures may be sizeable (and as large as the gap itself, as they found for US data). The data stem more from unreliable end-of-sample estimates of the trend rather than from revised estimates of the underlying data. As a possible remedy, Gerdrup and others (2013) and Farrell (2014) argue that augmenting historical observations with forecasts before applying the Hodrick-Prescott (HP) filter improves the properties of the credit gap. Similar in spirit to this paper, Kalatie and others (2015), after testing different transformations of the credit-to-GDP ratio and the credit-to-GDP gap on European country data, find strong crisis prediction power similar to that of the BCBS gap. Galán and Mencía (2018) apply unobserved component and vector autoregression models, accounting for a relationship between credit and other macrofinancial variables to produce credit imbalance estimations that are shown to better predict crises and present lower biases after rapid changes in fundamentals than the BCBS gap does.

A number of studies have found that alternative variables, such as house price growth or the debt-service-to-income ratio, tend to perform similarly well, especially in combination with the credit gap. For example, Behn and others (2013) find that a model combining the credit

quickly. Drehmann and others (2011) find that real credit growth and money growth (M2) as macro variables as well as credit spreads as market indicators can be promising predictors of an imminent crisis, justifying the release of the CCB. 
gap with global credit growth and augmented by house price growth and other control variables achieves the highest usefulness in predicting banking crises. Other studies stress the usefulness of information about debt service costs, exclusively or in addition to the credit gap (for example, Ramsey and Sarlin 2014; Drehmann and Juselius 2013; and Giese and others 2014). To be sure, many jurisdictions that implemented the CCB early on chose to rely on multiple indicators ${ }^{3}$, and the European Systemic Risk Board (ESRB; 2014) suggests that some countries may also want to apply alternative gap specifications and quantitative indicators. In line with legal requirements, all EU countries had put the CCB in place by January 2016.

One problem of the models for triggering the CCB is that they do not consider by how much a threshold is breached (Detken and others 2014). For calibration purposes, this judgment implies that the early warning models issue a signal but do not indicate the appropriate size of the buffer with which to address the impending systemic crisis (for a suitable approach, see Behn and others 2014). Studies contemplating whether the size of the buffer is sufficient to absorb subsequent losses assess the stability of the triggering signal, but fall short of analyzing what magnitude of losses the CCB ought to absorb (for example, Drehmann and others 2011). It is undeniable that excessive lending during the mid-2000s contributed greatly to the severity of the ensuing financial crisis ${ }^{4}$. But does this exuberance translate directly into equally extreme bank losses? And if so, what part of these extreme losses could reasonably be expected given the degree of economic contraction during the crisis?

\footnotetext{
${ }^{3}$ Among early adopters in Europe, Norway, a member of the European Economic Area, established the CCB in late 2013. In response to CRD IV, the Norwegian buffer guide prescribes that decisions on the CCB shall be based on the credit-to-GDP gap, but also other indicators (ratio of house prices to household disposable income, commercial property prices, and the wholesale funding ratio) and the central bank's assessment of the buildup of systemic risk (Norges Bank 2013). In Switzerland, a countercyclical buffer was predicated on a crisis in the late 1980s and seen as absorbing a large portion of crisis-related losses. The Swiss version of the CCB was activated in early 2013 and was increased from 1 percent to 2 percent in June 2014; early evidence (Basten and Koch 2015) suggests that the measure has had an effect, bolstering financial stability by diverting lending to more resilient banks. The buffer decisions are not driven by the credit gap concept, but rather by an array of key indicators, among which are mortgage volume and real estate price indicators (Swiss National Bank 2014). Mindful of the limitations of the credit gap, Spain uses several additional indicators (credit growth, real estate indicators, credit sustainability indicators, and global liquidity indicators (Castro and others 2016)). In the United Kingdom, buffer decisions are made on the basis of 18 indicators depicting bank balance sheet developments, credit and external variables, and market indicators (Bank of England, 2014). Among G20 countries outside Europe; Australia (2015) sets the CCB according to judgment about current levels of systemic risk, including credit growth, asset prices, and lending standards (APRA 2015); India uses the credit gap, albeit with a minimum and maximum threshold of 3 and 15 percent, respectively (RB, 2013); Saudi Arabia as of 2016, relies on the credit-to-GDP while reserving use of additional indicators (SAMA 2016); and South Africa assesses credit-to-GDP gaps for different credit products (SARB 2015).

${ }^{4}$ Jorda and others (2013) show that the economic cost of crises depends on the runup of debt during the preceding boom. Dell'Ariccia and others (2012) find in a cross-sectional regression for 21 European emerging market economies - conceptually similar to the one in this paper - that the cumulative growth of private sector credit-to-GDP during 2003-08 explains well the ensuing increase in the nonperforming loan ratio of the sample countries.
} 
This paper points to a number of conceptual issues in calibrating the CCB that arise in country cases where financial cycles are particularly short and financial intermediation is low, at least initially, as was the case in the transition economies. To accommodate such characteristics in some instances, the Basel credit-to-GDP gap may have to be adjusted using a different smoothing factor and accounting for the degree of financial deepening. In doing so, the paper employs a method that links cyclical overshooting and bank loan losses deserving to be covered by the CCB. In theory, losses in a downturn should be covered first by loan loss reserves, and to the extent that losses turn out to be larger than originally expected, by ordinary equity capital. Arguably, any remaining ("residual") losses that are not linked to the economic demise, but rather to overshooting in the boom phase, should be covered by an additional layer of capital, notably the CCB.

Based on cross-sectional regressions for a sample of EU countries, the paper shows that variables depicting unhealthy credit developments, first and foremost the Basel credit gap, can indeed explain the magnitude of such residual losses. The fit of the regressions is, however, improved when based on a variant of the Basel gap that uses a considerably lower smoothing factor to accommodate countries in the sample with short financial cycles, in this case the transition economies of Central and Eastern Europe. Most of these countries also have had a low degree of financial intermediation, which is why it also may be warranted to adjust the gap for the degree of financial deepening, as expressed by the credit-to-GDP ratio.

Moreover, the paper reflects upon the recommended calibration of the CCB given the cost of maintaining excessively large buffers over longer periods, that is, when the calibration produces a CCB that is arguably oversized in individual cases. Specifically, the paper considers a somewhat more systematic approach to calibrating the $\mathrm{CCB}$, particularly regarding the minimum and maximum threshold values of the credit gap that in line with BCBS (2010) are mapped into a CCB spanning 0 to 2.5 percent of RWA. The BCBS calibration underlying the thresholds of 2 percentage points ( $\mathrm{pp}$ ) of the credit-to-GDP ratio for the minimum and $10 \mathrm{pp}$ for the maximum gap was not communicated by the BCBS in much detail ${ }^{5}$ and, irrespective of the exact derivation, the thresholds are calibrated to ensure a good signaling property of the gap but not necessarily to associate the buffer size with a certain benchmark loss.

In fact, surprisingly few studies have called those specific thresholds into question. Implicitly pointing to the cost of maintaining large buffers when they may not be needed, Detken and others (2014) observe that the gap exceeded $\mathrm{H}=10$ (that is, $10 \mathrm{pp}$ ) outside crises or evaluation periods in $18 \mathrm{EU}$ member states and that for the EU as a whole, the upper threshold could be set at a somewhat higher rate than $\mathrm{H}=10$, even though in some of such periods the $\mathrm{CCB}$

${ }^{5}$ The BCBS (2010) buffer guide merely states: "BCBS analysis has found that an adjustment factor based on $\mathrm{L}=2$ and $\mathrm{H}=10$ provides a reasonable and robust specification based on historical banking crisis," while also admitting that certain parameters have played a role in bringing about this good fit: "However, this depends to some extent on the choice of the smoothing parameter (lambda), the length of the relevant credit and GDP data, and the exact setting of L and H," (BCBS 2010, pp. 13-14). 
would likely have been deactivated (Drehmann and Tsatsaronis 2014). Similarly, using a loss function approach, Detken and others (2014) find the minimum threshold of $\mathrm{L}=2$ to be broadly adequate, although the optimal threshold has a range of 1 to $3 \mathrm{pp}$, depending on policymakers' preferences for avoiding type I and II errors in predicting crises. The analysis in this paper picks up on that finding by assessing whether threshold specifications other than $\mathrm{L}=2 / \mathrm{H}=10$ can minimize deviations of the calibrated $\mathrm{CCB}$ from the theoretically optimal one when considering countries' residual losses and policymakers' preferences.

The paper is structured as follows. Section II provides a description of the variables and data sources as well as the econometric methodology applied. It also discusses a number of issues surrounding the calculation of the credit gap and presents some alternative variables. Section III presents the regression results that show how well the aforementioned variables are able to explain the residual loan losses obtained as errors from regressing overall loan losses on the change in GDP during the crisis. Section IV has the mapping of credit gaps into the CCB and gives a breakdown of losses to be covered by ordinary capital and the CCB. Section V assesses the performance of different gap threshold combinations in view of different preferences regarding buffer size. Section VI concludes.

\section{Data AND Methodology}

For the quantitative analysis, a parsimonious set of variables for the EU-27 countries ${ }^{6}$ was compiled. Accounting for earlier systemic crisis episodes would have been beneficial, but was not feasible because consistent EU-wide loan loss provisioning data were only available from 2007 - a fact that restricts this analysis to the episode of the global financial crisis. In a first step, a multivariate regression of loan impairments on GDP growth and the credit-toGDP gap is run. The dependent variable is the two-year cumulative flow of loan impairments. The independent variables are the two-year aggregate change in real GDP (for a definition, see below) and the Basel credit gap, alternatively with a low smoothing factor and normalized by the credit-to-GDP ratio. Separately, variables depicting pre-crisis growth of house and equity prices are also tested.

The regression outcome (Section III) illustrates that the magnitude of the economic downturn during the crisis and the pre-crisis credit-to-GDP gap jointly explain post-crisis loan impairments, with both covariates highly significant. The same holds true for economic growth in conjunction with house price growth.

Once the multivariate regression establishes that both the GDP growth during the crisis and the pre-crisis credit-to-GDP gap contribute to loan losses, we turn to a two-stage regression approach to isolate the effects of credit overshooting (measured by the pre-crisis credit-to-

\footnotetext{
${ }^{6}$ Croatia, as the $28^{\text {th }}$ EU country, was not included for reasons of data availability at the time of writing.
} 
GDP $\operatorname{gap}^{7}$ ) on subsequent loan losses. In the first-stage regression, the dependent variable is the ratio the sum of loan impairments (general and specific provisions) and other provisions ${ }^{8}$ to average total assets at the height of the crisis, either in 2008-09 or 2009-10 (only annual data are available), whichever aggregate provisioning number turned out to be higher ${ }^{9}$. This impairment variable is regressed on the two-year (more precisely, eight-quarter) percentage change in real GDP, starting from the quarter in which aggregate activity started falling at the onset of the global financial crisis, which was either in 2007 or 2008 . The paper focuses on cyclically induced losses more than on those that were arguably caused by second-round effects such as the European debt crisis and compounded the initial losses ${ }^{10}$.

In most EU countries, the deterioration in output thus preceded the hike in the selected provisioning flow ${ }^{11}$ so that the macrofinancial causality tends to run from the economy to the banking sector. It is important to mention that a certain reverse causality may have existed. The economic downturn could be propelled by credit losses (for example, European banks' early losses in the US market), may have existed. Also, a second-round impact of banking sector performance on real activity cannot be ruled out. Arguably, the loan losses close to the economic turning point are less "contaminated" by second-round effects than those in later years. In theory, it would also be sensible to include a variable that additionally explains the provisioning flow at the system level such as national regulation on timely recognition of losses or the lack thereof, but this is not feasible within this framework ${ }^{12}$. As another caveat,

\footnotetext{
${ }^{7}$ The credit gap was calculated using data from 1999 onward, notably the gap's maximum reading for each country. In the majority of countries, the gap peaked in 2005-06, particularly in the transition economies.

${ }^{8}$ Data source for impairments and provisions is the Statistical Data Warehouse of the European Central Bank. Other provisions for pending losses account for less than 10 percent of total provisioning costs but were included in the aggregate figure, as some countries do not publish a breakdown by component but rather a composite figure.

${ }^{9}$ In specifying the GDP growth variable, this two-year aggregate loss was chosen because it corresponded best to the available absorption capacity of the CCB at its regular maximum of 2.5 percent of RWA (Section IV). Note that the provisioning variable is a flow representing the expense of a rise in nonperforming loans and, as such, is not derived from a change in the stock of loan loss reserves.

${ }^{10}$ A number of countries (for example, Greece and Cyprus) recorded larger GDP contractions and thus loan losses in later years, but mainly due to idiosyncratic factors (notably, the effects of the European debt crisis of 2010-12), showing little relation to the credit cycle. A few other countries like Ireland experienced larger loan losses only after the three-year window (2008-10) used in this study, suggesting that a somewhat larger-thanestimated CCB level may be appropriate in individual cases. This argument is in line with the findings of de Haan and Kakes (2018), who show that retail-oriented banks, which weathered the 2007-2009 crisis relatively well, were particularly vulnerable to the subsequent European debt crisis, posting the highest peak accumulated losses.

${ }^{11}$ More specifically, for 18 out of the 27 countries, impairments lagged the GDP turning point (typically by two quarters), while in the remaining cases there was a lead of one quarter.

12 In practice, such qualitative summary indicators do not yet exist for a larger set of countries, and banks' often idiosyncratic provisioning policies do not lend themselves well to modeling. This is particularly true because banks in a number of countries may lawfully engage in forward-looking provisioning, thereby exceeding pointin-time expected loss, which may somewhat skew the impairment flows used here.
} 
the bank and output losses are confined to the country in question and do not incorporate those losses that were caused by cross-border exposures.

In the second-stage regression, the residuals from the first regression representing remaining (or "unexplained") loan losses were obtained and then regressed on one of the variants of the credit-to-GDP gap (using a one-sided HP filter) whose computation was based on at least five years of credit data ${ }^{13}$. The definition of the gap proposed by the BCBS (2010) was tested alongside a number of variants that may have a more robust relationship with residual loan losses than the BCBS gap.

In a final step, the fitted values from the second-stage regression were expressed in terms of RWA and then used for mapping residual losses to the size of the CCB. All regression equations estimated at the different stages are specified in section III. The credit gaps calculated here differ somewhat from those in BCBS (2010) and other studies because they are based on a different data source for credit $^{14}$.

By choice, the BCBS (2010) definition uses a very high smoothing factor for the filtered series of lambda $\lambda=400,000$. The BCBS based the decision in favor of this lambda on the assumption that the typical credit or financial cycle (as proxied by the period between systemic crises) is between three to four times longer than the business cycle ${ }^{15}$ and because $\lambda=400,000$ (implying a four-times longer duration of credit cycles) ${ }^{16}$ was found to outperform credit gaps based on smaller lambdas in predicting banking crises in a sample of G20 and

\footnotetext{
13 The computation of the credit gaps follows the BCBS methodology, that is, subtracting the one-sided Hodrick-Prescott filtered trend from the level of the credit-to-GDP series and using only data available in real time (for a detailed description, see Drehmann and Juselius (2014)). The gaps are based on at least five years of credit data, as that maximum credit gaps were reached no earlier than 2003 and as some credit series, notably in transition countries, started being published consistently only in the late 1990s. This lead time corresponds to what Drehmann and others (2011) use, but is lower than the 10 years of data in Drehmann and Juselius (2014).

${ }^{14}$ Consistent data for credit to the private sector in all 27 EU countries are available only from the IMF's International Financial Statistics (IFS), which report bank credit rather than the total credit (IFS, line 32d). Using a measure of broad credit, including cross-border flows, would have been preferable, as Drehmann and Tsatsaronis (2014) observe that Basel III suggests the use of data on total credit, capturing not only bank credit but all sources of credit, including bonds and cross-border finance, to the private nonfinancial sector, and that credit gaps based on total credit outperform the credit gaps based on bank credit as early warning indicators for banking crises. Unfortunately, the BCBS credit dataset, available at www.bis.org/statistics/credtopriv.htm and described in Dembiermont and others (2013), lacked data for one-third of the EU countries (9 out of 27, mostly transition economies). Another dataset, in part manually compiled for an ECB expert group, sought to close this gap for the EU countries outside the BCBS sample, but did not achieve sufficiently long series for broad credit with which to calculate the credit gap during the mid-2000s. For consistency, the quantitative analysis thus uses the narrower definition of bank credit to the private sector that underlies the credit gap calculations for the EU27. Regression output is unlikely to be greatly different, as the correlation between the broad and the narrow definition of credit ranges from 0.921 to 0.999 for the 18 EU countries in the BCBS dataset.

15 Arnold and others (2012) report that the typical length of the financial cycle ranges between 16 and 20 years.

${ }^{16}$ Under the assumption that credit cycles are four times as long as business cycles, the lambda of $\lambda=400,000$ is calculated as $4 \wedge 4 * 1600$ (Drehmann and others 2010; Edge and Meisenzahl 2011).
} 
OECD countries excluding transition economies (Drehmann and others 2010) ${ }^{17}$. At the same time, a high smoothing factor can lead to continuously positive credit gaps for more than 20 years, which illustrates the difficulty that such statistical tools have in distinguishing between cyclical developments and structural change (Detken and others 2014). The BCBS concept relates the fourfold duration of financial cycles to the (rare) occurrences of crises, yet for countries experiencing shorter cycles with large amplitudes (for example, transition economies), this strong smoothing may lead to implausibly large credit gaps.

Indeed, as the sample of European countries in the present study is rather heterogeneous, comprising roughly as many transition economies with rather volatile credit patterns as advanced economies, the typical duration of the most recent credit cycle in EU countries since the 1990s was calculated to be markedly shorter (between five and 10 years) than in the sample of Drehmann and others (2010). As a result, this study also sets out to test alternative credit gaps based on smaller lambdas (one-sided HP filter with $\lambda=1,600$, as generally recommended for quarterly data, and $\lambda=25,000$ as an "in-between" figure implying that credit cycles are approximately twice as long as business cycles) ${ }^{18}$.

For the same reason of heterogeneity, the credit-to-GDP gap series were additionally normalized by dividing each country's credit gap by its credit-to-GDP ratio. In the same vein, Lainà and others (2015) construct a relative gap by relating the deviation to the value of the trend. and others (2014) report lower average credit gaps for transition economies than for more mature ones, furnishing proof of the heterogeneity of the set of European countries, while Drehmann and Juselius (2014) observe that the credit gap is less informative as an early warning indicator for a set of smaller (non-G20) economies. Intuitively, a 1 percentage point gap in a financially less developed country - several European transition economies had credit-to-GDP ratios of less than 30 percent in the early 2000s - arguably has a higher impact on activity than such a gap in a mature economy with deep financial markets. This problem is acknowledged by the BCBS (2010) in its guidance for national authorities, but the guidance on how to operationalize the buffer guide in the presence of widely different creditto-GDP ratios is not particularly detailed ${ }^{19}$. The normalization performed here is one concrete way of dealing with this heterogeneity.

\footnotetext{
${ }^{17}$ The finding that moving toward a higher lambda improves the predictive quality of the credit gap indicator is confirmed, inter alia, by Bonfim and Monteiro (2013), who test the variable in a sample of nine advanced European countries. However, when testing the credit gap for Portugal, the authors find that the best prediction is achieved with a lambda of 1,600 - in line with this paper's notion that a lambda of 400,000, as suggested by BCBS (2010), is not always preferable. Jobst (2016) also uses a lambda of 1,600 in an analysis for the Slovak Republic.

${ }^{18}$ Valinskyte and Rupeikka (2015) find that for Lithuania, a complementary alternative gap measure, which is estimated using simple projections (that is, a smoothing parameter of 400,000, where data series are extrapolated with a weighted average of the past four quarterly observations) works better than the BCBS gap.

19 "It should be noted that fixing $\mathrm{L}$ and $\mathrm{H}$ at specific absolute levels means that, at the points at which the buffer guide turns on and reaches its maximum, the credit-to-GDP gap will vary as a percentage of the current credit-
}

(continued...) 
The descriptive statistics of the dependent variable and the set of explanatory variables used in the regressions are summarized in Table 1.

Table 1. Summary Statistics of Explanatory Variables

\begin{tabular}{|c|c|c|c|c|c|c|}
\hline Variable & Definition & Source & Mean & Std.Dev. & Min. & Max. \\
\hline Impairments & $\begin{array}{l}\text { Cumulative flows of impairments } \\
\text { and provisions during 2008-09 or } \\
2009-10 \text { (whichever number is higher), } \\
\text { in percent of average total assets }\end{array}$ & ECB & 2.48 & 2.18 & 0.36 & 8.47 \\
\hline GDP growth & $\begin{array}{l}\text { Largest cumulative eight-quarter } \\
\text { percentage change in real GDP during } \\
2007-10 \text { (starting quarter depending } \\
\text { on individual business cycle) }\end{array}$ & Eurostat & -6.03 & 5.79 & -23.80 & 5.46 \\
\hline \multirow{2}{*}{$\begin{array}{l}\text { Credit-to- } \\
\text { GDP gap }\end{array}$} & \multirow{2}{*}{$\begin{array}{l}\text { Maximum credit-to-GDP gap, BCBS } \\
(2010) \text { definition; alternatively, } \\
\text { credit gap with different lambdas and } \\
\text { normalized for credit-to-GDP levels }\end{array}$} & \multirow{2}{*}{$\begin{array}{l}\text { IMF / } \\
\text { own } \\
\text { calcu- } \\
\text { lations }\end{array}$} & $\begin{array}{c}\lambda=400,000: \\
12.66\end{array}$ & 10.61 & 2.72 & 50.41 \\
\hline & & & 8. & 5.72 & 2.15 & 20.53 \\
\hline $\begin{array}{l}\text { House price } \\
\text { growth }\end{array}$ & $\begin{array}{l}\text { Compound annual growth rate of } \\
\text { house prices during 2005-08 }\end{array}$ & OECD & 17.70 & 15.92 & 0.90 & 54.60 \\
\hline $\begin{array}{l}\text { Equity pric } \\
\text { growth }\end{array}$ & $\begin{array}{l}\text { Compound annual growth rate of } \\
\text { equity prices during 2005-08 }\end{array}$ & OECD & 36.70 & 17.43 & 12.00 & 80.20 \\
\hline
\end{tabular}

\section{REGRESSION RESULTS}

First, a multivariate setup is used, with the cumulative flow of loan impairments and other provisions (impairments) regressed on the two-year percentage change in real GDP (gdp_growth) and the preferred variant of the normalized Basel gap (credit_gap_normal) with a low smoothing factor $(\lambda=1,600)$. The following cross-section model was estimated, with robust standard errors to correct for heteroskedasticity (t-statistics in parentheses) ${ }^{20}$ :

to-GDP ratio. A consequence of this is that countries with a lower credit-to-GDP ratio can experience higher increases in credit as a percentage of current credit outstanding before the buffer guide turns on and before it reaches its maximum" (BCBS 2010, p. 14).

${ }^{20}$ Based on a skewness and kurtosis test for normality and a Shapiro-Wilk (1965) test, it was not possible to reject the hypothesis that the residuals from this regression are normally distributed. Still, based on an information matrix test for the regression model and an orthogonal decomposition into a Cameron and Trivedi (1990) test, the model is likely heteroskedastic, which requires estimating the model with robust standard errors following Efron (1981) and MacKinnon and White (1985). This version of robust errors based on a heteroskedasticity-consistent covariance matrix, termed $\mathrm{HC} 3$, was chosen in particular because the size properties of this type of test have been found to be good, even at a sample size of $n=25$, as is the case with the 


$$
\begin{aligned}
& \text { impairments }_{i}=-0.513-0.314 \text { gdp_growth }_{i}+0.128 \text { credit_gap_normal }_{i}+\varepsilon_{i} . \\
& (-1.34) \quad(-5.96)^{* * *} \quad(3.28)^{* * *}
\end{aligned}
$$

The regression results show that both explanatory variables are highly significant at the 1 percent level with the expected signs $\left(\mathrm{R}^{2}\right.$ of 0.83$)$.

As an alternative to the credit gap, the compound growth rates of house and equity prices are tested. It turns out that house prices are also a highly significant determinant of impairments after controlling for economic growth, while equity prices are not.

$$
\begin{aligned}
& \text { impairments }_{i}=0.028-0.243 \text { gdp_growth } i+0.088 \text { house_price_growth } i+\varepsilon_{i} \text {. } \\
& (0.11) \quad(-4.54)^{* * *} \quad \text { (3.30)*** } \\
& \text { impairments }_{i}=-0.487-0.312 \text { gdp_growth }{ }_{i}+0.055 \text { equity_price_growth }{ }_{i}+\varepsilon_{i} \text {. } \\
& (-0.71) \quad(-4.98)^{* * * *} \quad \text { (1.18) }
\end{aligned}
$$

Looking at the correlation between the drivers of loan impairments, we find that there is hardly any correlation between GDP growth and the different credit gap measures (between 0.00 and 0.09, Table 2), and moderate correlation between GDP and house price growth.

\section{Table 2. Correlation Coefficients of GDP Growth}

\begin{tabular}{lc}
\hline Credit gap, BCBS definition, $\lambda=400,000$ & 0.086 \\
Credit gap, normalized, $\lambda=400,000$ & -0.001 \\
Credit gap, normalized, $\lambda=25,000$ & -0.027 \\
Credit gap, normalized, $\lambda=1,600$ & -0.052 \\
Compound house price growth & -0.474 \\
Compound equity price growth & -0.118
\end{tabular}

As there is no meaningful correlation between GDP growth and any of the credit gap measures, the regression setup is changed in favor of a two-stage regression, also for expositional purposes. The idea is to single out residual losses that are obtained as the error terms from a first-stage regression of impairments on GDP growth.

The regression residuals are then regressed on different measures of the credit gap. The following first-stage regression is estimated:

$$
\text { impairments }_{i}=\underset{(1.06)}{0.555-} \underset{(-5.21)^{* * *}}{0.320} \text { gdp_growth } h_{i}+\varepsilon_{i} .
$$

present sample. In general, HC3 is seen as superior for tests of coefficients that are most likely affected by heteroskedasticity (Long and Ervin 2000). To be sure, it produces the most conservative t-values.

(continued...) 
Figure 1 shows that the regression fit is good, corresponding to an $\mathrm{R}^{2}$ of 0.72 . The chart also informs that there is arguably only one outlier country, Poland (PL) ${ }^{21}$, whose banks suffered non-negligible losses despite the country's remarkable economic resilience in the crisis.

\section{Figure 1. Scatter Plot of Regression of Loan Impairments on Change in Real GDP}

(Loan impairments in percent of total assets)

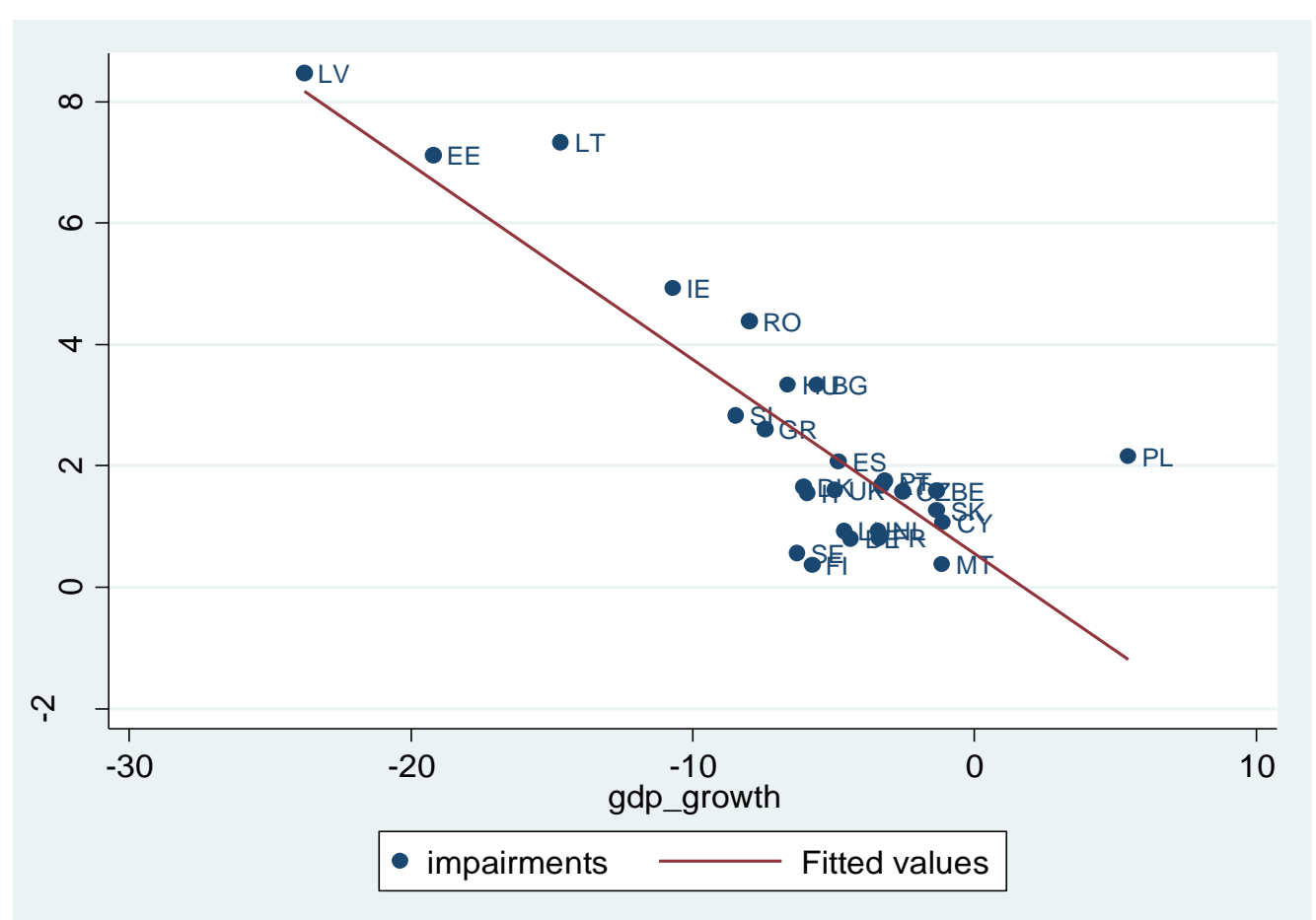

Source: ECB and Eurostat data, and author's calculations

As is evident from Figure 1, the slope coefficient is influenced by the developments in a number of transition economies (but not exclusively, as Ireland (IE) and Greece (GR) also stand out)).

The residuals $\left(\varepsilon_{i}\right)$ of this regression, which represent the loan losses (both positive and negative) not explained by the economic downturn, were obtained and in the second stage regressed on one of the variants of the credit-to-GDP gap:

$$
\text { residuals(first_stage })_{i}=\alpha+\beta \text { credit_gap } i+\varepsilon_{i} \text {. }
$$

\footnotetext{
${ }^{21}$ Exclusion of this observation improves the $\mathrm{R}^{2}$ to 0.83 , while increasing the slope coefficient to -3.75 . However, as the country's credit gap is in the mid-range of the distribution, such exclusion would not change the slope coefficient in the second-stage regression much (by 0.019 , while improving the $\mathrm{R}^{2}$ by 0.06 ). Because of this and the small sample size, it was decided not to discard this observation.
} 
The results of the second-stage regressions are shown in Table 3.

Table 3. Results of Regressions of Residual Losses on Credit Gaps

\begin{tabular}{lccc}
\hline Gap definition/lambda & $\lambda=400,000$ & $\lambda=25,000$ & $\lambda=1,600$ \\
\hline \multirow{2}{*}{ Maximum, BCBS definition } & 0.007 & 0.005 & 0.000 \\
\multirow{2}{*}{ Maximum, BCBS def. normalized } & $(0.31)$ & $(0.18)$ & $(0.00)$ \\
& 0.077 & 0.084 & $\mathbf{0 . 1 2 6}$ \\
\hline
\end{tabular}

Note: Constant terms not reported; t-statistics in parentheses. ***,**, * denote significance at the $1 \%, 5 \%, 10 \%$ levels.

A number of insights can be gleaned from the second-stage regression results.

First, the maximum (largest observed) gap in line with the BCBS (2010) gap definition $(\lambda=400,000)$ does not produce a significant outcome. This is not to say that the standard Basel credit gap does not work for many of the European countries. Rather, the failure is likely owed to the heterogeneity of the country sample which, as mentioned, comprises a large number of transition countries that started from a low level of credit-to-GDP. When normalizing the credit gaps to properly account for the impact of smaller gaps in financially less-developed countries, the adjusted maximum gap measure immediately attains significance at the 5 percent level.

Second, applying a lower smoothing factor than the original lambda $=400,000$ in the extraction of credit gaps improves the regression outcome as well, mainly because the credit cycles of several transition countries were rather short (five to 10 years, not 20 years). Using a smaller lambda better accommodates sudden starts and stops that a number of transition countries experienced and corrects some implausibly large gaps produced by the BCBS gap definition. The preferred gap variant is the normalized maximum gap using a lambda of 1,600 (termed gapmax1600), whose regression fit $\left(\mathrm{R}^{2}=0.39\right)$ is displayed in Figure 2 (twoyear cumulative residual losses regressed on the adjusted credit gap). 
Figure 2. Regression of Residual Loss Values on Normalized Maximum Credit Gap $(\lambda=1,600)$

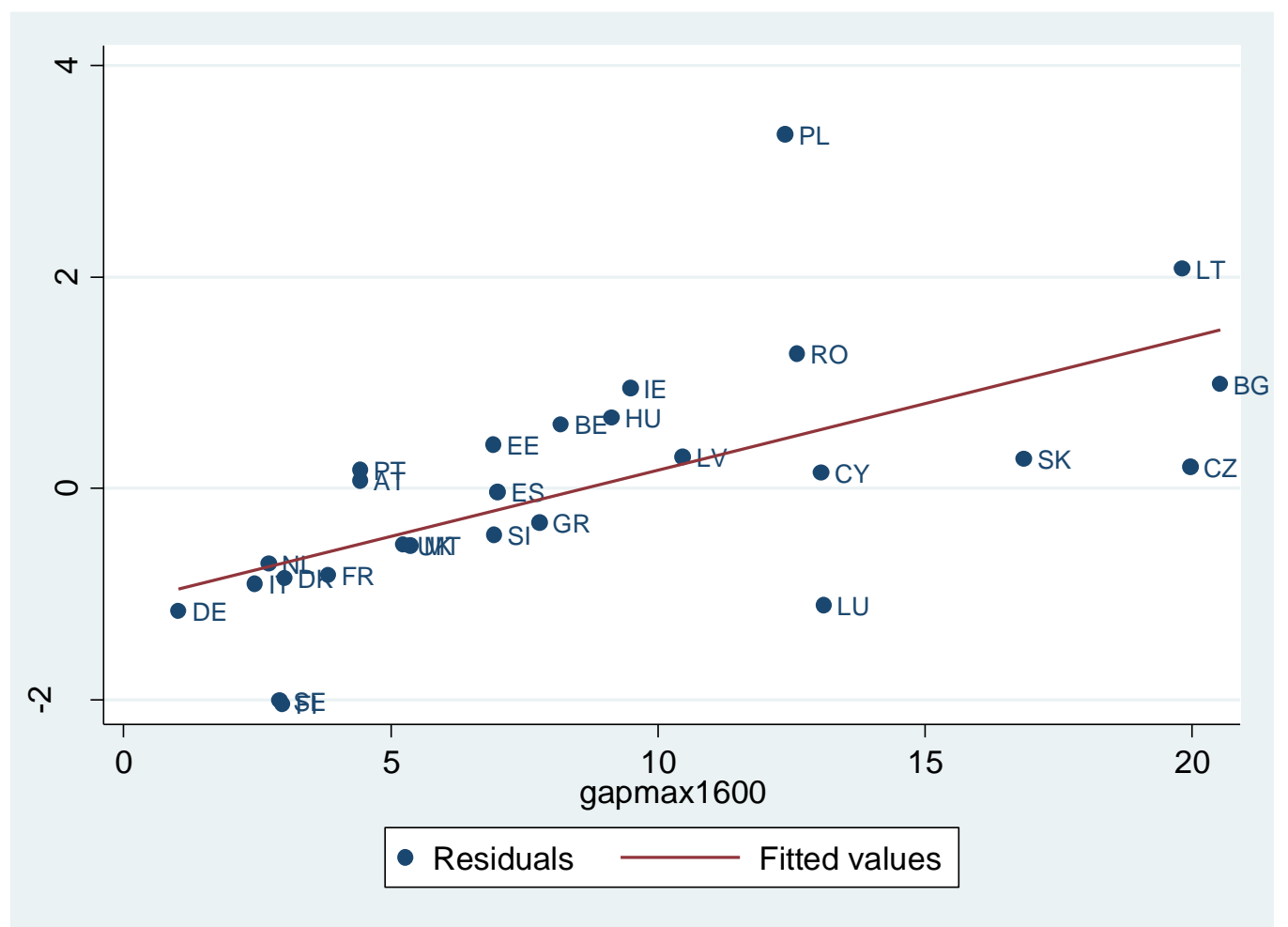

Source. Author's calculations

To be sure, this result by no means invalidates the numerous findings in the literature that the Basel credit gap using a high smoothing factor $(\lambda=400,000)$ is the best crisis predictor in the range of possible credit gaps and for an even wider range of alternative variables for that matter. The Basel gap specification simply does not perform well for this rather heterogeneous set of European countries.

\section{CCB VERSUS ORDINARY BUFFER}

It is instructive to take the two-stage regression approach a step further and map the normalized credit gap into the CCB. The fitted values from the second-stage regression constitute the basis for the mapping of residual losses into the recommended size of the CCB. Taking the fitted values from the second-stage regression rather than the observed ones was considered appropriate because rather large deviations in single cases would have led to implausible buffer sizes notwithstanding the good fit of the previous regression. Since the residual loan losses are expressed in terms of total assets, they needed to be transformed into RWA terms ${ }^{22}$.

${ }^{22}$ This transformation procedure was preferred because absolute values of risk weighted assets were not available. The alternative of using RWA-adjusted losses in the first-stage regression was discarded as it would have introduced measurement error already then. 
The adjusted values were then mapped into the size of the CCB, with the CCB activated beyond a credit gap of 4 percent $(\mathrm{L}=4)$ and increasing linearly with the credit gap up to 2.5 percent of RWA corresponding to a maximum gap of 20 percent $(\mathrm{H}=20)^{23}$. In assessing buffer adequacy, one should conceptually distinguish between the ordinary buffer and the $\mathrm{CCB}$, being mindful of the distinct purposes they are supposed to serve. While not a regulatory concept, the ordinary buffer can be thought of as the combined cushion of loan loss provisions and equity capital, the latter being included to deal with possible underprovisioning in the stock of provisions. It should serve to absorb expected losses (given the economic contraction), while also being available to address unexpected losses, and is expressed here in percent of total assets (Table 4, second column). By contrast, the CCB could be construed to cover residual losses brought about by excessive lending in the upswing phase.

Assuming that banks must always honor the minimum capital requirement, the "usable" ordinary buffer is calculated as the difference between total buffer expressed in RWA terms and the minimum required buffer assumed to be 8 percent of RWA (Table 4, fifth column). This usable buffer is to absorb expected losses (already expressed in RWA terms; third column), while the CCB is to cover residual losses, as obtained from the first-stage regression (also in RWA terms, fourth column, and calibrated on the maximum credit gap in $0.25 \mathrm{pp}$ increments, third column in from the right. As a result, countries can have a surplus or a shortfall in their ordinary buffers and in their CCBs.

Figure 3 outlines the breakdown of loss absorption by buffer type for a sample country (Estonia), with losses exceeding the available reserves buffer and, hence, the need to build a CCB.

\section{Figure 3. Absorption of Total Loss-Breakdown by Buffer Type}

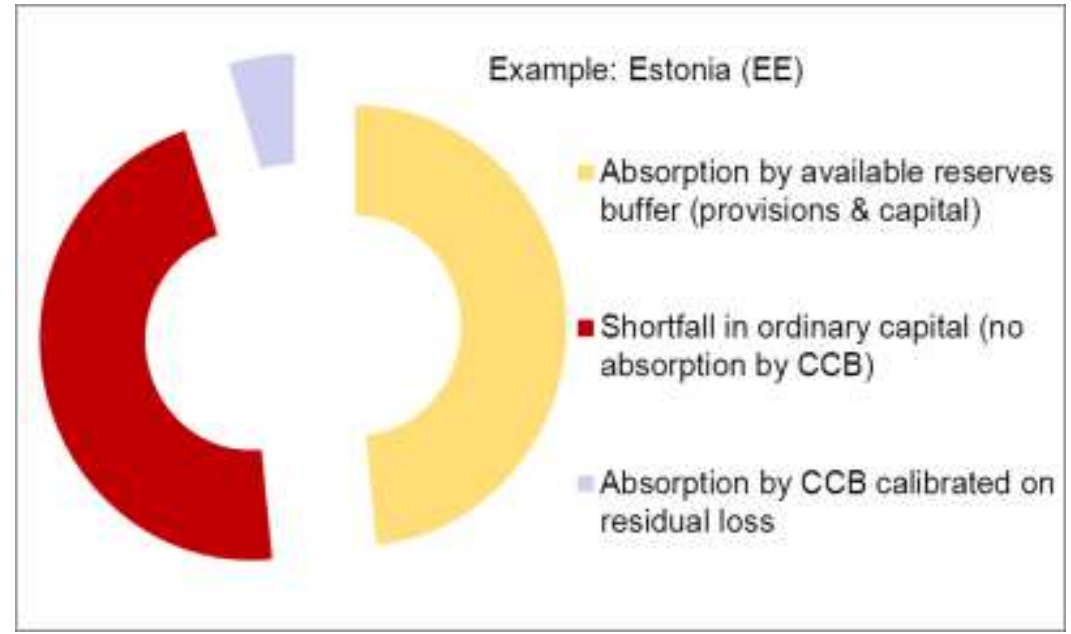

Source. Author's calculations

${ }^{23}$ This contrasts with $\mathrm{L}=2$ and $\mathrm{H}=10$ under the BCBS approach, but the concept of activating the CCB when the gap is at one-fifth of the maximum gap is maintained. 
Table 4. Buffers versus Losses (CCBs Based on Normalized Credit Gap), in percent

\begin{tabular}{|c|c|c|c|c|c|c|c|c|c|}
\hline Country & $\begin{array}{c}\text { Total } \\
\text { Buffer/ } \\
\text { Assets }\end{array}$ & $\begin{array}{c}\text { Expected } \\
\text { Loss/ } \\
\text { RWA }\end{array}$ & $\begin{array}{c}\text { Residual } \\
\text { Loss/ } \\
\text { RWA }\end{array}$ & $\begin{array}{c}\text { Usable } \\
\text { Buffer/ } \\
\text { RWA }\end{array}$ & $\begin{array}{c}\text { Excess } \\
\text { Capital/ } \\
\text { RWA }\end{array}$ & $\begin{array}{c}\text { Shortfall } \\
\text { Capital/ } \\
\text { RWA }\end{array}$ & $\begin{array}{c}\text { Mapped } \\
\text { CCB/ } \\
\text { RWA }\end{array}$ & $\begin{array}{c}\text { Excess } \\
\mathrm{CCB} / \\
\mathrm{RWA}\end{array}$ & $\begin{array}{c}\text { Shortfall } \\
\text { CCB/ } \\
\text { RWA }\end{array}$ \\
\hline $\mathrm{AT}$ & 7.00 & 2.85 & 0.13 & 4.39 & 1.54 & & 0.25 & 0.12 & \\
\hline $\mathrm{BE}$ & 4.11 & 2.48 & 1.52 & 2.35 & & 0.13 & 0.75 & & 0.77 \\
\hline BG & 10.84 & 2.88 & 1.22 & 5.33 & 2.45 & & 2.50 & 1.28 & \\
\hline $\mathrm{CY}$ & 9.08 & 1.61 & 0.26 & 7.96 & 6.35 & & 1.50 & 1.24 & \\
\hline $\mathrm{CZ}$ & 9.35 & 2.84 & 0.42 & 11.28 & 8.44 & & 2.50 & 2.08 & \\
\hline DK & 6.63 & 4.33 & 0.00 & 9.40 & 5.07 & & 0.00 & & \\
\hline $\mathrm{EE}$ & 9.13 & 9.40 & 0.58 & 4.79 & & 4.61 & 0.50 & & 0.08 \\
\hline FI & 5.83 & 0.87 & 0.00 & 6.15 & 5.28 & & 0.00 & & \\
\hline FR & 5.48 & 2.73 & 0.00 & 10.27 & 7.53 & & 0.00 & & \\
\hline $\mathrm{DE}$ & 4.67 & 2.89 & 0.00 & 8.86 & 5.97 & & 0.00 & & \\
\hline GR & 6.21 & 4.24 & 0.00 & 2.10 & & 2.15 & 0.75 & 0.75 & \\
\hline $\mathrm{HU}$ & 7.68 & 3.88 & 0.97 & 3.15 & & 0.73 & 1.00 & 0.03 & \\
\hline IE & 4.52 & 8.11 & 1.91 & 1.21 & & 6.91 & 1.00 & & 0.93 \\
\hline IT & 7.68 & 2.67 & 0.00 & 5.22 & 2.55 & & 0.00 & & \\
\hline LV & 8.26 & 10.62 & 0.38 & 2.73 & & 7.89 & 1.25 & 0.87 & \\
\hline $\mathrm{LT}$ & 8.00 & 7.04 & 2.78 & 2.72 & & 4.32 & 2.50 & & 0.28 \\
\hline LU & 4.22 & 2.58 & 0.00 & 3.69 & 1.11 & & 0.25 & 0.25 & \\
\hline MT & 8.03 & 0.63 & 0.00 & 5.34 & 4.71 & & 0.25 & 0.25 & \\
\hline NL & 5.06 & 2.49 & 0.00 & 5.57 & 3.07 & & 0.00 & & \\
\hline PL & 10.89 & 0.00 & 4.55 & 6.80 & 6.80 & & 1.50 & & 3.05 \\
\hline $\mathrm{PT}$ & 8.10 & 2.33 & 0.26 & 4.00 & 1.67 & & 0.25 & & 0.01 \\
\hline RO & 10.78 & 4.67 & 1.91 & 8.14 & 3.47 & & 1.50 & & 0.41 \\
\hline SK & 9.48 & 3.85 & 0.41 & 6.28 & 2.43 & & 2.25 & 1.84 & \\
\hline SI & 8.39 & 1.52 & 0.00 & 2.10 & 0.58 & & 0.50 & 0.50 & \\
\hline ES & 6.93 & 3.39 & 0.00 & 3.34 & & 0.05 & 0.50 & 0.50 & \\
\hline SE & 5.15 & 1.29 & 0.00 & 3.87 & 2.58 & & 0.00 & & \\
\hline UK & 6.80 & 5.18 & 0.00 & 13.86 & 8.69 & & 0.25 & 0.25 & \\
\hline
\end{tabular}

Source: Author's calculations

Notes: "Total buffer" is CCB plus ordinary buffer (common capital and provisions). "Expected loss" and "residual loss" correspond to the the fitted values and the residuals of the first-stage regression, respectively. "Usable buffer" equals total buffer minus the minimum capital requirement ( 8 percent of RWA). "Excess (shortfall) capital" is the difference between usable capital and expected loss, and "excess (shortfall) CCB" is the difference between mapped CCB and necessary CCB (not shown). 
As seen in Table 4, some countries (Ireland (IE), Latvia (LV) and, to a lesser extent, Estonia (EE) and Lithuania (LT)) would have profited from an extra buffer in absorbing large expected losses that the existing ordinary buffer could not. A number of countries (Belgium (BE), Estonia (EE), Ireland (IE), and Lithuania (LT)) show shortfalls both in their calibrated CCBs and the ordinary buffers in place when the economic downturn hit.

Nine countries (one third of the sample) show excess ordinary buffers and CCBs, while, as mentioned, only four suffer shortfalls in both buffers. Another seven countries with excess ordinary buffers would not need to build CCBs under the credit gap mapping. The remaining seven countries show a shortfall in the CCB and an excess in the primary buffer or vice versa. In some cases, though, the CCB shortfall is minor compared to the excess in the overall buffer (Poland (PL), Portugal (PT), and Romania (RO)).

\section{V.SENSITIVITY ANALYSIS}

Making the concept operational in real time, however, raises a specific control issue. In theory, no outright triggering mechanism is needed for this methodology to work, as the CCB is activated at the discretion of the competent authorities. This is the case in our mapping when the credit gap surpasses $\mathrm{L}=4$ (or $\mathrm{L}=2$, in line with BCBS, 2010). Still, it should be ensured that the near-optimal size of the buffer is in place during a sufficiently long period in advance of a presumed crisis episode.

The concern is that the proposed residual loss methodology may not trigger the buildup phase in time, in case the largest credit gap determining the CCB size is reached only close to the economic downturn or even thereafter. The same concern applies to an early triggering of the buffer and a subsequent premature drawdown well ahead of a crisis. In other words, it may well be that an evidently suboptimal buffer is in place just before an impending crisis. This section evaluates the optimality of the buffer calibration during certain evaluation periods.

One of the requirements of a well-functioning CCB is that the buffer is built well ahead of a looming systemic crisis. According to BCBS (2010) and Drehmann and Juselius (2014) and in line with CRD IV, the signal should be issued with a lead time of at least four to six quarters for policymakers to assess relevant information and then instruct the banks accordingly, giving them sufficient time to build the necessary buffer. In addition, policymakers act without the benefit of hindsight so that only information that is available in real time should be evaluated.

Closer examination of the timing of the threshold and maximum gaps for each country suggests that the timing concern is valid. While under our setup with $\mathrm{L}=4 / \mathrm{H}=20$, the maximum gap is reached seven quarters before the economic downturn on average (median), the standard deviation is large at $5.5 \mathrm{pp}$, implying that for a number of countries the maximum is reached well before the cyclical turning point or, in rare instances, actually thereafter, neither of which is a desirable outcome. 
Obviously, mapping the CCB in line with the BCBS (2010) guide with $\mathrm{L}=2 / \mathrm{H}=10$ will extend the time span during which the buffer is potentially at (or above) the required level. At the same time, this calibration also tends to produce higher excess buffers for most countries in the sample.

This evident tradeoff has largely been overlooked in the literature, although an analysis of whether other settings of the credit gap threshold could reduce costs relative to benefits should be part of the judgment that is expected in the deployment of the CCB (van Norden 2011; Kowalik 2011). The notable exception is the work by Drehmann and Juselius (2014), who examine whether an indicator has the right timing during a certain forecast horizon and whether its stability deteriorates when the horizon is shortened ${ }^{24}$.

In the following, a set of different minimum-maximum threshold combinations is evaluated. The aim is to find the calibration that during a certain evaluation period minimizes the surpluses and deficits in buffers relative to the CCB size required for individual countries. Recall that the needed buffer size depends on the residual losses from the first-stage regression, expressed in RWA terms.

In total, nine combinations are examined, three each with the minimum gap at one-fifth, onethird, and one-half of the maximum gap, and within these sets the maximum gap amounting to 10,15 , and 20 percent. This approach is related to the Area Under the Receiver Operator Characteristic (AUROC) concept in the early warning literature that measures the relationship between correctly called crises and false alarms under varying indicator thresholds, summarizing the validity of a given indicator in the AUROC ${ }^{25}$. Applied to the problem at hand, the tradeoff consists in min-max combinations that cause positive and negative deviations from the individually optimal buffer size.

In this assessment, the number of periods between one and three years [t-4, t-11] ahead of the individual GDP turning point is evaluated as to the deviation of the point-in-time buffer from the required one. For example, if the residual loss amounts to 0.9 percent of RWA, the buffer size needs to be at least 1 percent, bearing the rule of $0.25 \mathrm{pp}$ increments in mind. For each min-max combination, this translates into a different credit gap such as 4.4 percent under the $\mathrm{L}=2 / \mathrm{H}=10$ mapping or 8.8 percent under $\mathrm{L}=4 / \mathrm{H}=20$. If the actual credit gap happens to be below (above) this target gap, a deficit (surplus) in buffer size results.

Figure 4 shows a hypothetical path of buffer sizes relative to an assumed required buffer of 1 percent during an eight-quarter period $[\mathrm{t}-4, \mathrm{t}-11]$; periods $[\mathrm{t}-0, \mathrm{t}-3]$ are not evaluated, as they are too close to the crisis to be operationally feasible.

\footnotetext{
${ }^{24}$ Drehmann and Juselius (2014) find that both credit gap and debt service ratio are remarkably stable over time. The stability of the signal is also considered in Detken and others (2014).

${ }^{25}$ For more information on the AUROC concept, see, for example, Detken and others (2014) or Drehmann and Tsatsaronis (2014).
} 
Figure 4. Hypothetical Determination of Deviations from Necessary CCB Size

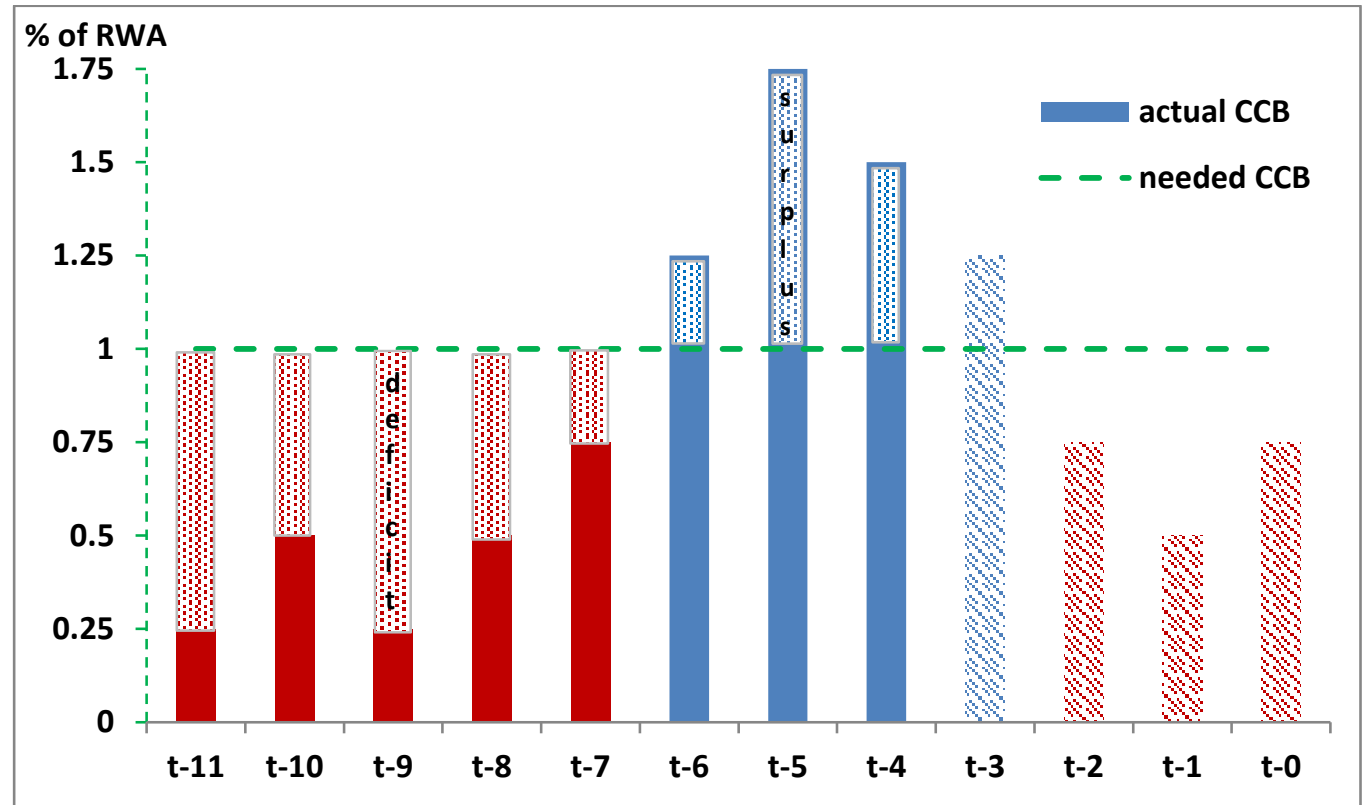

In the spirit of Borio and Drehmann (2009) and Krüger and Libertucci (2013), the deviations from the required size in absolute terms, here marked as light-shaded bars, are summed up and then averaged over the 27 countries, which is equivalent to the mean root square distance to the reference point. The overall deviations resulting of each min-max combination are summarized in Table 5.

Table 5. Ranking of Minimum-Maximum Combinations, Eight-Quarter Evaluation Interval [t-4, t-11]

\begin{tabular}{|l|c|c|c|c|c|c|c|c|c|}
\hline & $\begin{array}{c}\mathrm{L}=2 / \\
\mathrm{H}=10 /\end{array}$ & $\begin{array}{c}\mathrm{L}=3 / \\
\mathrm{H}=15\end{array}$ & $\begin{array}{c}\mathrm{L}=4 / \\
\mathrm{H}=20\end{array}$ & $\begin{array}{c}\mathrm{L}=3.3 / \\
\mathrm{H}=10\end{array}$ & $\begin{array}{c}\mathrm{L}=5 / \\
\mathrm{H}=15\end{array}$ & $\begin{array}{c}\mathrm{L}=6.6 / \\
\mathrm{H}=20\end{array}$ & $\begin{array}{c}\mathrm{L}=5 / \\
\mathrm{H}=10\end{array}$ & $\begin{array}{c}\mathrm{L}=7.5 / \\
\mathrm{H}=15\end{array}$ & $\begin{array}{c}\mathrm{L}=10 / \\
\mathrm{H}=20\end{array}$ \\
\hline $\begin{array}{l}\text { Deviation from } \\
\text { needed CCB size }\end{array}$ & 0.444 & 0.360 & $\mathbf{0 . 3 4 5}$ & 0.405 & 0.368 & 0.349 & 0.382 & 0.363 & 0.359 \\
\hline Rank & 9 & 4 & $\mathbf{1}$ & 8 & 6 & 2 & 7 & 5 & 3 \\
\hline
\end{tabular}

Source: Author's calculations

Based on the evaluation period of eight quarters [t-4, t-11], the original BCBS (2010) mapping turns out not to be optimal under our setup, but the adjusted BCBS mapping with $\mathrm{L}=4 / \mathrm{H}=20$ is, followed by the other combinations with $\mathrm{H}=20$. In general, however, the differences between the nine combinations are not very large. If instead of equal weights for upward and downward deviations either one is given double weight (weighting $2 / 3$ versus $1 / 3$ or, equivalently, a preference parameter $\mu^{26}$ of 0.67 or 0.33 ), the ranking changes toward the "corner" combinations. A policymaker's dislike of insufficient buffers (expressed by

\footnotetext{
${ }^{26}$ The parameter $\mu$ depicts a policymaker's preference for avoiding missed crises relative to avoiding false alarms (Betz and others 2013). Here, a dislike of insufficient buffers is broadly equivalent to a dislike of missing crises.
} 
$\mu=0.67$ ) will favor combinations with relatively low minimum thresholds (in this case, $\mathrm{L}=3.3 / \mathrm{H}=10, \mathrm{~L}=3 / \mathrm{H}=15$ and $\mathrm{L}=2 / \mathrm{H}=10)$.

In the reverse case of a dislike of excessive buffers (i.e. $\mu=0.333$ ) implying high costs, the $\mathrm{L}=10 / \mathrm{H}=20$ mapping turns out to be optimal ${ }^{27}$. This sensitivity analysis illustrates that the mapping choice is a matter of policy preferences after all.

Table 6. Ranking of Minimum-Maximum Gap Combinations, Using Unequal Weights

\begin{tabular}{|l|c|c|c|c|c|c|c|c|c|}
\hline & $\begin{array}{c}\mathrm{L}=2 / \\
\mathrm{H}=10 /\end{array}$ & $\begin{array}{c}\mathrm{L}=3 / \\
\mathrm{H}=15\end{array}$ & $\begin{array}{c}\mathrm{L}=4 / \\
\mathrm{H}=20\end{array}$ & $\begin{array}{c}\mathrm{L}=3.3 / \\
\mathrm{H}=10\end{array}$ & $\begin{array}{c}\mathrm{L}=5 / \\
\mathrm{H}=15\end{array}$ & $\begin{array}{c}\mathrm{L}=6.6 / \\
\mathrm{H}=20\end{array}$ & $\begin{array}{c}\mathrm{L}=5 / \\
\mathrm{H}=10\end{array}$ & $\begin{array}{c}\mathrm{L}=7.5 / \\
\mathrm{H}=15\end{array}$ & $\begin{array}{c}\mathrm{L}=10 / \\
\mathrm{H}=20\end{array}$ \\
\hline $\begin{array}{l}\text { Deviation, dislike } \\
\text { of deficit buffers }\end{array}$ & 0.362 & 0.355 & 0.384 & $\mathbf{0 . 3 5 3}$ & 0.401 & 0.421 & 0.362 & 0.425 & 0.463 \\
\hline Rank & 3 & 2 & 5 & $\mathbf{1}$ & 6 & 7 & 3 & 8 & 9 \\
\hline $\begin{array}{l}\text { Deviation, dislike } \\
\text { of excess buffers }\end{array}$ & 0.527 & 0.365 & 0.307 & 0.457 & 0.334 & 0.278 & 0.402 & 0.301 & $\mathbf{0 . 2 5 6}$ \\
\hline Rank & 9 & 6 & 4 & 8 & 5 & 2 & 7 & 3 & $\mathbf{1}$ \\
\hline
\end{tabular}

Source: Author's calculations

The choice of the [t-4, t-11] interval is guided by the need for a reasonably long evaluation period as close to the cyclical peak as is practical, but other evaluation windows may be sensible as well. As a further sensitivity check, the min-max combinations are tested with three other intervals ranging between four and 12 quarters: [t-4, t-7], [t-4, t-15], and [t-6, t11]. Limiting the analysis to the first case of equal weights for deficits and surpluses, the results illustrate that min-max combinations with a high upper threshold $(\mathrm{H}=20)$ are by and large superior, although once again the difference across combinations are not large. In each case, however, the BCBS (2010) mapping $\mathrm{L}=2 / \mathrm{H}=10$ ranks lowest under this setup.

Table 7. Ranking of Minimum-Maximum Gap Combinations, Different Evaluation Intervals

\begin{tabular}{|l|c|c|c|c|c|c|c|c|c|}
\hline & $\begin{array}{c}\mathrm{L}=2 / \\
\mathrm{H}=10 /\end{array}$ & $\begin{array}{c}\mathrm{L}=3 / \\
\mathrm{H}=15\end{array}$ & $\begin{array}{c}\mathrm{L}=4 / \\
\mathrm{H}=20\end{array}$ & $\begin{array}{c}\mathrm{L}=3.3 / \\
\mathrm{H}=10\end{array}$ & $\begin{array}{c}\mathrm{L}=5 / \\
\mathrm{H}=15\end{array}$ & $\begin{array}{c}\mathrm{L}=6.6 / \\
\mathrm{H}=20\end{array}$ & $\begin{array}{c}\mathrm{L}=5 / \\
\mathrm{H}=10\end{array}$ & $\begin{array}{c}\mathrm{L}=7.5 / \\
\mathrm{H}=15\end{array}$ & $\begin{array}{c}\mathrm{L}=10 / \\
\mathrm{H}=20\end{array}$ \\
\hline $\begin{array}{l}\text { Deviation; 4-qtr. } \\
\text { interval [t-4, t-7] }\end{array}$ & 0.430 & 0.348 & $\mathbf{0 . 3 3 0}$ & 0.392 & 0.353 & 0.331 & 0.371 & 0.345 & 0.339 \\
\hline Rank & 9 & 5 & 1 & 8 & 6 & 2 & 7 & 4 & 3 \\
\hline $\begin{array}{l}\text { Deviation, 12-qtr. } \\
\text { interval [t-4, t-15] }\end{array}$ & 0.657 & 0.556 & $\mathbf{0 . 5 4 4}$ & 0.608 & 0.569 & 0.550 & 0.582 & 0.564 & 0.567 \\
\hline Rank & 9 & 3 & 1 & 8 & 6 & 2 & 7 & 4 & 5 \\
\hline $\begin{array}{l}\text { Deviation, 6-qtr. } \\
\text { interval [t-6, t-11] }\end{array}$ & 0.333 & 0.300 & 0.298 & 0.313 & 0.300 & $\mathbf{0 . 2 9 4}$ & 0.304 & 0.299 & 0.295 \\
\hline Rank & 9 & 5 & 3 & 8 & 5 & $\mathbf{1}$ & 7 & 4 & $\mathbf{2}$ \\
\hline
\end{tabular}

Source: Author's calculations.

Another insight from this analysis is that the six-quarter interval [t-6, t-11] has both the lowest deviations overall and also the small differences between the highest and lowest ranking combinations. In fact, the least favorable mapping still has a lower average deviation

${ }^{27}$ Notice that the difference to the runner-up combinations is larger than in the first instance, which means that the difference in the equal-weights case (Table 6) is largely driven by the differences in excess buffers caused by the individual min-max combinations. 
$(\mathrm{L}=2 / \mathrm{H}=10,0.333)$ than the best combinations under the eight- and 12-quarter approaches. This finding suggests that this particular six-quarter interval could serve as a relatively reliable buffer guide, implying that periods earlier than $\mathrm{t}-11$ or later than $\mathrm{t}-6$ would be disregarded, as they tend to produce more suboptimal buffer sizes on average. However, even the preferred mappings with $\mathrm{L}=4 / \mathrm{H}=20$ and $\mathrm{L}=6.6 / \mathrm{H}=20$ are far from perfect, producing inadequate buffers in some cases. As Table 8 illustrates, a policymaker with a strong preference for sufficiently large buffers (quadruple weighting of $4 / 5 \mathrm{vs}$. $1 / 5$, or $\mu=0.8$ ) would minimize the deviations, particularly the downward ones, by choosing a low-threshold combination such as $\mathrm{L}=2 / \mathrm{H}=10$ (here using the six-quarter evaluation interval). Equivalently, a policymaker with converse preferences $(\mu=0.2)$ would choose the highest minimum threshold combination $(\mathrm{L}=10 / \mathrm{H}=20)$.

Table 8. Ranking of Minimum-Maximum Gap Combinations, Using Strongly Unequal Weights

\begin{tabular}{|l|c|c|c|c|c|c|c|c|c|}
\hline & $\begin{array}{c}\mathrm{L}=2 / \\
\mathrm{H}=10 /\end{array}$ & $\begin{array}{c}\mathrm{L}=3 / \\
\mathrm{H}=15\end{array}$ & $\begin{array}{c}\mathrm{L}=4 / \\
\mathrm{H}=20\end{array}$ & $\begin{array}{c}\mathrm{L}=3.3 / \\
\mathrm{H}=10\end{array}$ & $\begin{array}{c}\mathrm{L}=5 / \\
\mathrm{H}=15\end{array}$ & $\begin{array}{c}\mathrm{L}=6.6 / \\
\mathrm{H}=20\end{array}$ & $\begin{array}{c}\mathrm{L}=5 / \\
\mathrm{H}=10\end{array}$ & $\begin{array}{c}\mathrm{L}=7.5 / \\
\mathrm{H}=15\end{array}$ & $\begin{array}{c}\mathrm{L}=10 / \\
\mathrm{H}=20\end{array}$ \\
\hline $\begin{array}{l}\text { Deviation, strong } \\
\text { dislike of deficits }\end{array}$ & $\mathbf{0 . 3 0 2}$ & 0.349 & 0.364 & 0.311 & 0.354 & 0.389 & 0.327 & 0.383 & 0.411 \\
\hline Rank & $\mathbf{1}$ & 4 & 6 & 2 & 5 & 8 & 3 & 7 & 9 \\
\hline $\begin{array}{l}\text { Deviation, strong } \\
\text { dislike of surpluses }\end{array}$ & 0.365 & 0.252 & 0.232 & 0.316 & 0.247 & 0.200 & 0.280 & 0.215 & $\mathbf{0 . 1 7 9}$ \\
\hline Rank & 9 & 6 & 4 & 8 & 5 & 2 & 7 & 3 & $\mathbf{1}$ \\
\hline
\end{tabular}

Source: Author's calculations.

\section{CONCLUSIONS}

In closing, the objective of the paper is to point to issues in CCB calibration that may emerge when countries feature some unusual characteristics like short financial cycles and low financial deepening. In such cases, it could be preferable to modify the Basel calibration approach by using a lower smoothing factor and possibly also adjusting the credit gap for the degree of financial deepening as expressed, for example, by the credit-to-GDP ratio. These characteristics were observed in European transition economies during the past decade. Using data for the EU-27 countries, the paper shows that the BCBS credit gap does not work well, because of the heterogeneity of the sample comprising roughly as many transition economies as mature ones. However, this conclusion might be different if using a broader set of countries or a different time horizon.

The paper employs a residual loss concept that relates loan losses not explained by the economic downturn in 2008-09 to the credit booms preceding the crisis as measured by the BCBS credit gap. The distinction between ordinary and residual losses also serves to assign the CCB the specific task of absorbing losses that exceed expected losses and ordinary unexpected losses to be covered by provisions and regular capital, respectively. Such residual losses arise from overshooting of the financial cycle in a boom phase, and the CCB should ideally be calibrated as an additional buffer to cover extraordinary losses linked to such lending sprees. The analysis shows that, in the European context, the credit-to-GDP gap becomes a robust explanatory variable for these residual losses only after a couple of 
adjustments are made, notably applying a lower smoothing factor and normalizing the credit gap to a country's credit-to-GDP level. This is done to accommodate the many volatile economies in the sample. The Basel gap is likely to work fine in a restricted sample containing more mature economies, but such a small sample would not lend itself to regression analysis here.

Another contribution of the paper is to reexamine the BCBS buffer guide using different thresholds for minimum and maximum gaps/CCB sizes, as policymakers may have different preferences for avoiding insufficient buffers versus shunning high costs of excessive buffers. If losses are large and cannot be fully covered under the maximum gap threshold, the BCBS buffer guide is adequate only for policymakers who want to safeguard against insufficient buffers in the run-up phase using a low minimum threshold. By contrast, those with more balanced preferences would likely choose higher thresholds considering the cost of excessive buffers that needs to be viewed in relation to the losses to be covered. The choice of a particular buffer guide also depends on the interval during which deviations from the required buffer size are analyzed, although it is not clear that longer intervals would necessarily suggest different optimal threshold combinations than shorter intervals.

In calibrating the $\mathrm{CCB}$, policymakers not only have the option to modify the credit gap but to use other indicators, either in isolation or in addition to the credit gap. The paper points to the merit of house price growth as a triggering variable, as found elsewhere in the literature. But there may be other indicators, or a combination of indicators, that predict crises better in individual country cases than the credit gap in isolation does. As the paper illustrates, this choice should also take into account policymakers' objectives and risk tolerance. After all, the BCBS buffer guide represents merely an input to the decision-making process of national authorities rather than an automatism, and it may be complemented by other methods such as stress testing. Indeed, the paper intends to provide food for thought and so foment the ongoing discussion on the rigorous calibration of the CCB as it is implemented around the globe. 


\section{REFERENCES}

Aiyar, S., C.W. Calomiris, J. Hooley, Y. Korniyenko, and T. Wieladek (2014a): "The international transmission of bank capital requirements," Journal of Financial Economics 113(3): 368-82.

Aiyar, S., C.W. Calomiris, and T. Wieladek (2014b): "Does Macro-Prudential Regulation Leak? Evidence from a UK Policy Experiment," Journal of Money, Banking and Credit 46(1): 181-214.

Arnold, B., C. Borio, L. Ellis, and F. Moshirian (2012): "Systemic risk, macroprudential policy frameworks, monitoring financial systems and the evolution of capital adequacy," Journal of Banking and Finance 36: 3,125-32.

Australian Prudential Regulation Authority (2015): "The countercyclical capital buffer in Australia," Information Paper, December.

Bank of England (2014): “The Financial Policy Committee’s Powers to supplement capital requirements - A policy statement," January.

Basel Committee on Banking Supervision (BCBS) (2010), "Guidance for national authorities operating the countercyclical capital buffer," December.

Basten, C., and C. Koch (2015): "Higher Capital Requirements and Mortgage Pricing: Evidence from the Countercyclical Capital Buffer (CCB)," BIS Working Paper No. 511.

Behn, M., C. Detken, T.A. Peltonen, and W. Schudel (2013): "Setting Countercyclical Capital Buffers based on Early Warning Models_-Would it Work?” ECB Working Paper No. 1604.

Behn, M., M. Groß, T. Peltonen, and W. Schudel (2014): "Calibrating countercyclical capital buffers with an integrated early warning GVAR model," European Central Bank (mimeo).

Bendoratyte, A., and D. Kaupelyte (2013): "Formation of countercyclical capital buffer in the European developing countries," Taikomoji Ekonomika: Sisteminiai Tyrimai, 2013.7/2

Betz, F., S. Oprică, T. Peltonen, and P. Sarlin (2013): "Predicting Stress in European Banks," ECB Working Paper No. 1597.

Bonfim, D., and N. Monteiro (2013): "The Implementation of the Countercyclical Capital Buffer: Rules Versus Discretion,” Banco de Portugal Financial Stability Report, November, 87-110.

Borio, C., and M. Drehmann (2009): "Assessing the Risk of Banking Crises-Revisited," BIS Quarterly Review, March, 29-46.

Cameron, A.C., and P.K. Trivedi (1990): "The information matrix test and its applied alternative hypotheses," Working Paper No. 372, University of California-Davis, Institute of Governmental Affairs. 
Castro, C., Á. Estrada, and J. Martínez (2014): "The Countercyclical Capital Buffer in Spain: An Exploratory Analysis of Key Guiding Indicators,” Banco de España Estabilidad Financiera 27, 31-59.

Castro, C., Á. Estrada, and J. Martínez (2016): "The Countercyclical Capital Buffer in Spain: An Analysis of Key Guiding Indicators," Banco de España Documentos de Trabajo No. 1601.

Central Bank of the Russian Federation (2016): “On countercyclical buffer to capital adequacy ratio," Communication, February 24.

De Haan, L., and J. Kakes (2018): "European banks after the global financial crisis: Peak accumulated losses, twin crises and business models," DNB Working Paper No. 600, July.

Dell'Ariccia, G., D. Igan, L. Laeven, H. Tong, B. Bakker, and J. Vandenbussche (2012): "Policies for Macrofinancial Stability: How to Deal with Credit Booms," IMF Staff Discussion Note 12/06. Washington: International Monetary Fund.

Dembiermont, C., M. Drehmann, and S. Muksakunratana (2013): "How much does the private sector really borrow-a new database for total credit to the private non-financial sector," BIS Quarterly Review, March, 65-81.

Detken, C., O. Weeken, L. Alessi, D. Bonfim, M.M. Boucinha, S. Frontczak, G. Giordana, C. Castro, J. Giese, N. Jahn, J. Kakes, B. Klaus, J.H. Lang, N. Puzanova, and P. Welz (2014): "Operationalising the countercyclical capital buffer: indicator selection, threshold identification and calibration options," European System Risk Board Occasional Paper No. 5.

Drehmann, M., C. Borio, L. Gambacorta, G. Jiménez, and C. Trucharte (2010):

"Countercyclical capital buffers: exploring options," BIS Working Papers No. 317.

Drehmann, M., C. Borio, and K. Tsatsaronis (2011): "Anchoring countercyclical capital buffers: The role of credit aggregates," International Journal of Central Banking 7(4): 189240.

Drehmann, M., and M. Juselius (2012): "Do debt service costs affect macroeconomic and financial stability?” BIS Quarterly Review, September, 21-34.

Drehmann, M., and M. Juselius (2014): "Evaluating early warning indicators of banking crises: Satisfying policy requirements," International Journal of Forecasting 22(3): 493-518.

Drehmann, M., and K. Tsatsaronis (2014): “The credit-to-GDP gap and countercyclical capital buffers: questions and answers,” BIS Quarterly Review, March: 55-73.

Edge, R.M., and R.R. Meisenzahl (2011): "The Unreliability of Credit-to-GDP Ratio Gaps in Real Time: Implications for Countercyclical Capital Buffers," International Journal of Central Banking 7(4): 261-98.

Efron, B. (1981): "Nonparametric estimates of standard error: The jackknife, the bootstrap and other methods," Biometrika 68: 589-99. 
European Systemic Risk Board (2014): "Recommendation of the European Systemic Risk Board of 18 June 2014 on guidance for setting countercyclical buffer rates," ESRB/2014/1.

European Union (2013): “Directive 2013/36/EU of the European Parliament and of the Council of 26 June 2013 on access to the activity of credit institutions and the prudential supervision of credit institutions and investment firms, amending Directive 2002/87/EC and repealing Directives 2006/48/EC and 2006/49/EC."

Farrell, G. (2014): "Countercyclical capital buffers and real-time credit-to-GDP estimates: A South African perspective,” Munich Personal RePEc Archive Paper No. 55368, http://mpra.ub.uni-muenchen.de/55368/.

Forbes, K., D. Reinhardt, and T. Wieladek (2016): “The Spillover, Interactions, and (Un)Intended Policy Consequences of Monetary and Regulatory Policies," NBER Working Paper No. 22307.

Galàn, J.E., and J. Mencía (2018): "Empirical Assessment of Alternative Structural Methods for Identifying Cyclical Systemic Risk in Europe,” Banco de España Documentos de Trabajo No. 1825.

Gerdrup, K., A.B. Kvinlog, and E. Schaanning (2013): "Key indicators for a countercyclical capital buffer in Norway_Trends and uncertainty," Norges Bank Staff Memo No. 13/2013.

Geršl, A., and J. Seidler (2011), "Excessive Credit Growth as an Indicator of Financial (In)Stability and its Use in Macroprudential Policy," Czech National Bank Financial Stability Report 2010/2011: 112-22.

Giese, J., H. Andersen, O. Bush, C. Castro, M. Farag, and S. Kapadia (2014): "The Credit-toGDP Gap and Complementary Indicators for Macroprudential Policy: Evidence from the U.K.," International Journal of Finance and Economics, 19: 25-47.

Jobst, A. (2016): "Macroprudential Measures for Tackling Excessive Credit Growth: The Counter-cyclical Capital Buffer and Beyond," IMF Country Report No. 16/14 (Selected Issues Paper, Slovak Republic). Washington: International Monetary Fund.

Jorda, O., M. Schularick, and A.M. Taylor (2013):" When credit bites back," Journal of Money, Credit and Banking, 45(2): 3-28.

Kalatie, S., H. Laakkonen, and E. Tölö (2015): "Indicators used in setting the countercyclical capital buffer," Bank of Finland Research Discussion Paper No. 8.

Kauko, K. (2012): “Triggers for countercyclical capital buffers," Bank of Finland BoF Online $7 / 2012$

Kelly, R., K. McQuinn, and R. Stuart (2011): "Exploring the Steady-State Relationship between Credit and GDP for a Small Open Economy-The Case of Ireland," Central Bank of Ireland Research Technical Paper 01/RT/11. 
Kowalik, M. (2011): “Countercyclical Capital Regulation: Should Bank Regulators Use Rules or Discretion?" Federal Reserve Bank of Kansas City Economic Review, Second Quarter: 63-84.

Krüger, U., and M. Libertucci (2013), "Does the Basel III countercyclical capital buffer mitigate capital procyclicality? Evidence from empirical tests," Banca d'Italia Working Paper (mimeo).

Lainà, P., J. Nyholm, and P. Sarlin (2015): "Leading indicators of systemic banking crises: Finland in a panel of EU countries," ECB Working Paper No. 1758.

Long, J.S., and L.H. Ervin (2000): "Using Heteroscedasticity Consistent Standard Errors in the Linear Regression Model," The American Statistician 54(3): 217-24.

MacKinnon, J.G., and H. White (1980): "Some heteroscedastic consistent covariance matrix estimators with improved finite sample properties," Journal of Econometrics 29: 53-7.

Monetary Authority of Singapore (2015): Financial Stability Review, November.

Norges Bank (2013): “Criteria for an appropriate countercyclical capital buffer," Norges Bank Papers No. 1/2013.

Ramsay, B.A., and P. Sarlin (2014): "Ending over-lending: Assessing systemic risk with debt to cash flow," Bank of Finland Research Discussion Paper 11/2014.

Repullo, R., and J. Saurina (2011): "The Countercyclical Capital Buffer of Basel II: A Critical Assessment," CEMFI Working Paper No. 1102.

Reserve Bank of India (2013): "RBI releases Draft Report on Implementation of Countercyclical Capital Buffer Framework in India,” Press Release, December 2.

Saudi Arabian Monetary Authority (2016): “Applicability of Countercyclical Capital Buffer (CCyB) in Saudi Arabia," communication to banks, January 4.

Shapiro, S.S., and M.B. Wilk (1965): "An analysis of variance test for normality (complete samples)," Biometrika 52: 591-611.

South African Reserve Bank (2015): Financial Stability Review, September.

Swiss National Bank (2014): "Implementing the countercyclical capital buffer in

Switzerland: concretising the Swiss National Bank's role, http://www.snb.ch/en/mmr/reference/CCB\%20communication/source/CCB\%20communication.en.pdf.

Valinskyte, N., and G. Rupeika (2015): "Leading Indicators for the Countercyclical Capital Buffer in Lithuania," Lietuvos Bankas Occasional Paper Series 04/2015.

Van Norden, S. (2011): "Discussion of the Unreliability of Credit-to-GDP Ratio Gaps in Real Time: Implications for Countercyclical Capital Buffers," International Journal of Central Banking 7(4): 299-303. 